\title{
Koloskopi eller kolonoskopi?
}

\author{
Endoskopisk undersøkelse av tykktarmen utføres vanligvis ved hjelp av en bøyelig fiberoptisk slange som \\ føres inn i tarmen via endetarmsåpningen. I medisinsk litteratur bruker man både begrepet «koloskopi» \\ og «kolonoskopi» om undersøkelsen. Hva betyr imidlertid disse ordene, og kan de kalles synonymer?
}

I engelsk litteratur er betegnelsen «colonoscopy» (kolonoskopi) betydelig mer utbredt enn «coloscopy» (koloskopi). Ifølge Tidsskriftets ordliste skal imidlertid undersøkelsen omtales som «koloskopi» (1). Søk i PubMed (1.2. 2015) gir hele 29971 treff på «colonoscopy» og sparsomme 403 på «coloscopy».

I velrenommerte medisinske tidsskrifter som New England Journal of Medicine (NEJM), Journal of the American Medical Association (JAMA) og BMJ finner man samme tendens - det er langt hyppigere bruk av «colonoscopy» enn av «coloscopy». Søk på Tidsskriftets nettsider (1.2. 2015) viser derimot et inverst forhold av begrepsbruken, med 119 treff på «koloskopi» og kun ett på «kolonoskopi» (2).

\section{Koloskopi}

Ordet «koloskopi» er sammensatt av de to greske ordene кó $\lambda$ ov (eng. «colon») og $\sigma \kappa о \pi \iota \alpha$ («scopia»), hvor sistnevnte er en avart av ordet $\sigma \kappa о \pi \varepsilon ́ \omega$ («scopeo», herav «skop»), som betyr å observere eller å undersøke med øyne eller sinn. Colon består av ordstammen «col-» og endelsen «-on».

Fordi ordstammen er avgjørende ved konstruksjon av sammensatte ord, er det i utgangspunktet kun «kol-» som viderefører betydningen av «colon» i denne sammenhengen. Teoretisk sitter man dermed igjen med det sammensatte ordet «kolskopi». Selv om «kolskopi» teknisk sett er riktig betegnelse, er det fonetisk tungvint å uttale ls-lyden. En bindevokal (-o-) blir derfor lagt til for å gjøre ordet mer flytende, slik at den endelige betegnelsen blir kol-o-skopi (koloskopi, eng. «coloscopy») (3).

\section{Når endelsen ikke faller langt fra stammen}

Tar man derimot utgangspunkt i det sammensatte ordet kolon-o-skopi (kolonoskopi), er det rimelig å anta at «colon» utgjør stammen i det første av de to ordene. «Colon» utgjør besynderlig nok stammen $i$ et annet gresk ord, ко $\lambda \omega v$ óç (colonos), som betyr «ås» (eng. «hill»). Den direkte oversettelsen av kolon-o-skopi (kolonoskopi) blir dermed «undersøkelse av åsen», som er både grammatisk og semantisk feil (3), med forbehold om at man ikke faktisk mener undersøkelse av åsen.

Andre eksempler på ord som er sammensatt på tilsvarende måte er rekt-o-skopi (rektoskopi) og bronk-o-skopi (bronkoskopi). Selv om ordet «kolonoskopi» synes å være utbredt særlig i engelskspråklig litteratur, hører man sjelden om «rektumoskopi» og «bronkusoskopi», som begge vil være feil på lik linje med «kolonoskopi». Videre vil korrekt navn på instrumentene som brukes være henholdsvis koloskop, rektoskop og bronkoskop.

I Audun Øyris medisinske ordbok er verken koloskopi eller kolonoskopi angitt som oppslagsord. Imidlertid finner man her oppslagsordet «koloskop» (4), som er korrekt; dessverre er «colonoscop» feilaktig angitt som synonym.

\section{Konklusjon}

Koloskopi er et medisinsk fagord som betyr undersøkelse av tykktarm, mens kolonoskopi har en helt annen betydning som gjør ordet unyttig i medisinsk terminologi. Koloskopi og kolonoskopi kan derfor ikke kalles synonymer.

Til slutt kan man spørre seg selv hvorfor undersøkelsen ikke har et lengre navn, siden koloskopi vanligvis også omfatter undersøkelse av endetarm (rectum), blindtarm (coecum) og distale tynntarm. Svaret på dette er sannsynligvis at det fulle navnet på en slik undersøkelse ville blitt svært langt og tilsvarende lite brukervennlig. Dersom valget står mellom «koloskopi» og «kolonoskopi» i betydningen «undersøkelse av tykktarm», finnes det uansett bare ett riktig alternativ: koloskopi. Tegnsetting med kolon (:) er for øvrig en annen historie.

Jeg takker Marius Kalsås Worren for nyttige kommentarer og innspill.

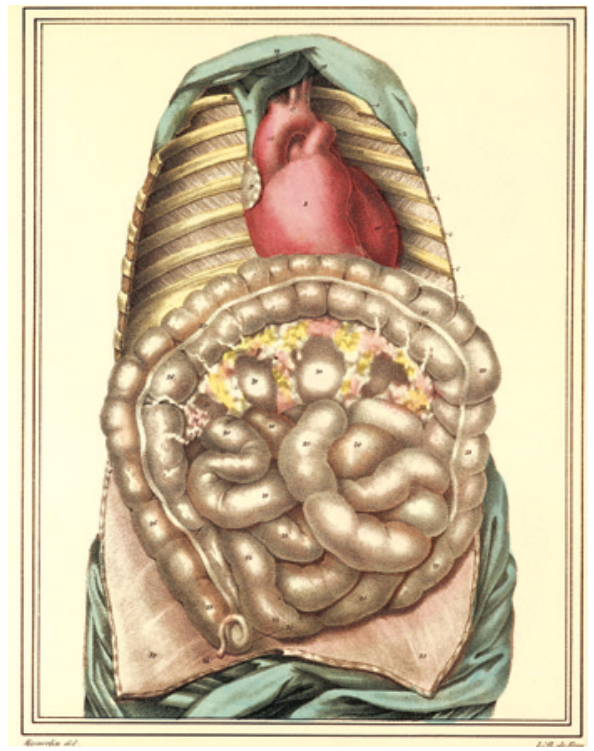

Fra Jules Germain Cloquets anatomiske atlas Manuel d'anatomie descriptive du corps humain, utgitt i 1825 i Paris. Foto: Science Photo Library

\section{Eirik Madsen}

eirik.madsen@helse-bergen.no

Eirik Madsen (f. 1987) er cand.med. fra Universitetet i Bergen og turnuslege ved Førde sentralsjukehus.

Litteratur

1. Tidsskriftets ordliste. http://tidsskriftet.no/ Innhold/Forfatterveiledningen/Spraak/Ordliste/K (1.2.2015).

2. Moum B. Prognose og behandling ved kronisk inflammatorisk tarmsykdom. Tidsskr Nor Lægeforen 2001: 121: 318-21.

3. Anastassiades CP, Cremonini F, Hadjinicolaou D. Colonoscopy and colonography: back to the roots Eur Rev Med Pharmacol Sci 2008; 12: 345-7.

4. Øyri A. Norsk medisinsk ordbok. 8. utg. Oslo: Samlaget, 2007: 540.

Mottatt 3.2. 2015 og godkjent 19.2. 2015. Redaktør: Marit Skaar Fjellhaug. 